\title{
Evaluation of Principal Role on Building Teachers' Competence in Man Kendari, Southest Sulawesi, Indonesia
}

\author{
Zulkifli M. ${ }^{1}$ \\ ${ }^{1}$ Islamic State Institute of Kendari \\ Correspondence: Zulkifli M. E-mail: zulkiflim58@ymail.com \\ Received: October 1, 2017 \\ doi:10.5539/ass.v13n12p132 \\ Accepted: October 17, $2017 \quad$ Online Published: November 28, 2017 \\ URL: https://doi.org/10.5539/ass.v13n12p132
}

\begin{abstract}
This study aims at analyzing the evaluation of principal's role in training teachers' competence in MAN 1 Kendari, Southeast Sulawesi Kendari. Subjects in this study are principals and teachers of MAN I Kendari. The research used descriptive method with qualitative approach. All the data collected by observation, interview and documentation and analyzed by data collection, data reduction, data presentation and conclusion. The result showed that the evaluation of principal role in building teachers' competence run well. In addition, the principal role as a leader trained the cooperation among administrators in the school, teachers and students' parents relates to students' education whether in the school or out of the school and socialization activities done by the teachers through teachers' group working (Kelompok Kerja Guru / KKG) to improve teachers' competence. As educator, the principal attempted to train the pedagogic competence and professional in terms of facilitating teachers to actively participate in KKG in order to improve teachers' ability in classroom management. In addition, as the supervisor, the principal trained teachers' pedagogic and personal in the classroom supervision activities, conducting meeting relates to the outcome of learning and instruction, arranging its scenario and the interaction process among teacher and students in the classroom.
\end{abstract}

Keywords: evaluation of principal's role, training of teachers' competence

\section{Introduction}

Act No. 20 of 2003 on National Education System Article 35 paragraph 1 explains that the National Standards consists of the standard content, processes, graduate outcomes, educational personnel, facilities and equipment, management, funding, and educational assessment, which should be improved systematically and regularly which aims to develop students' potentials to become a man of faith and piety to God Almighty, noble, healthy and responsible. Article 40 paragraph 2 of the Act also states that, educators and educational personnel have the responsibility to: a) create an meaningful, joyful, dynamic, and mutually interactive education environment; b) demonstrate professional commitment to the improvement of the quality of education; c) be the role model and uphold the reputation of their institution, profession, and position in accordance with the trust deposited in him (Depdiknas, 2004).

Based on the above Acts, the principal has a great responsibility in the management of the school and has a very important role in improving the quality of teachers through school programs. Likewise, Mulyasa (2013) states that in the line of duty, principal should have the institutional vision, a clear conceptual ability, and skill and art of human relations, mastery of the technical aspects and substantive.

In the efforts to improve the quality of national education, government, especially through Kemendikbud continuously tries to do a variety of changes and updates to the national education system. One of the efforts is associated with the teacher factor. Basically, the enactment of Act No. 14 of 2005 on Teachers and Lecturers and Government Regulation No. 19 Year 2005 on National Education Standards, is a government policy in which includes of government efforts to organize and to improve teachers' quality in Indonesia. Michael G. Fullan as cited in Suyanto and Asep Jihad (2013) suggested that change and reformation in education system is very dependent on the mastery of teachers' competence.

Moreover, teachers competences are now presumably still vary. Danim (2011) revealed t ohat one feature of the education crisis in Indonesia is teachers do not have adequate ability to show their work performance. This suggests that teacher performance is not fully supported by an adequate degree of competence mastery. Hence, it is strongly need comprehensible approach to improve the teachers' competence.

Along with the lack of teachers' pedagogical, personality, social, and professional, it will have an impact on the less optimal learning in school. It is apparent from the results of preliminary observations made by researchers at MAN I Kendari, that is, students had not arranged and managed properly, there was the lack of an open view to allow students to develop an interest respectively, there were still lack programs which lead to the society and education advancement and there was still no breach of discipline, such as being as late to school, due to lack of efforts to be made by the principal in carrying out supervision and regular monitoring, moreover teachers' mentoring or coaching individually and classically had not scheduled properly. 
Based on preliminary observations conducted at Madrasah Aliyah Negeri 1 Kendari, the head of the madrasah has not fully implemented his role as a fostering the development of competence to the teachers. This is due to busyness in carrying out other duties as head of the madrasah, so that adequate planning is required in the fostering of all aspects of the responsibility and the leadership of head madrasah can be done well. By implementing the tasks of heads of madrasah in various fields, it is necessary to do an adequate evaluation by the head of the madrasah of teachers and all staff within the scope of madrasah, especially related to the development of teacher competence in madrasah Aliyah Negeri 1 Kendari. It is important to do research on the role of head madrasah in developing teacher competence in MAN I Kendari.

Based on the above rationales, this study conducted to gain an overview of the evaluation on the principal's role in coaching teachers' competence of teachers in MAN I Kendari. The results of this study is very useful for the principals / madrasah in evaluating its role in developing teacher competence, especially teacher I MAN Kendari. In addition it is useful for teachers in an effort to develop their competence in order to improve the quality of education in general.

\section{The Essence of Principal}

According to Djafri, Novianty (2016), principal is the functional staff of teachers who is given task to lead a school where the learning process held or where there is interaction between teachers who give lessons and pupils who receive lessons. In institutional school, principle or more popularly known as the "teacher who received additional duties as head of the school." is one of the components that plays a role in improving education quality. As stated in article 12, paragraph 1 year 1990 that, principal responsible is for educational organization, school administration, coaching other education personnel, efficiency and maintenance of facilities and infrastructure. Therefore, a principal should prepare a particular strategy to improve his/her teachers' competency (Depdiknas, 2006).

Vannebo and Ottesen (2012) stated that leadership is currently seen as a guarantee for education quality and reform, as an essential component of building school capacity and as a major contributor to the transformation of practice.

The success of an educational institution is highly dependent on school leadership. Since the principal is as a leader in the institution, it has become a necessity for him/her to be able to bring the institution towards the achievement of defined objectives, to see the changes and the future in better globalization life. Principal should be responsible for the smooth running and success of all regulatory matters and the organizing formally or informally to his superiors to the people who have entrusted their children to the institution..

Based on the above explanation, it can be concluded that the principal is a teacher who is given the authority to direct the entire personnel in the school and has position as a determinant direction of the institution, set up all school programs, becomes carriers of the spirit of teachers' work and as the builders of culture for schools in improving the education quality.

According to Daryanto (2001), the duties and functions of the principal as educational leader as follows:

a. School planning in the sense of setting school direction as an educational institution is by formulating the vision, mission, goals and strategies.

b. Organizing school in the sense of making the organizational structure, assigning staffs and also assigning their duties and functions.

c. Moving the staffs in terms of motivating staff through internal marketing and external marketing.

d. Supervising in the sense of supervising, controlling and guiding all the staff and the school community.

e. Evaluating the process and outcomes of education to be the basis of education and the quality of growth, as well as performing both analytical problem solving both systematically and creative problem solving, moreover avoiding and resolving conflicts.

In addition, Mulyasa (2003) suggests that one's leadership is closely related to the personality and as a leader, he/she will be reflected by (1) honesty; (2) self-reliance; (3) responsibility; (4) willing to take risks and decisions; (5) high-minded; (6) emotionally stable, and (7) exemplary.

The learning activities are at the core of the educational process. In line with this, teacher is the executor and main developer of the curriculum in schools. In tem of principal as an educator, Principals who demonstrates a high commitment and focuses on curriculum development and teaching and learning in school would be very concerned about the level of competency of the teacher, as well as he/she will always strive to facilitate and encourage teachers to continually improve their competence, so that teaching and learning activities can run effectively and efficiently.

As supervisor, to determine the extent to which the teacher is able to carry out learning, principal needs to regularly carry out supervision activities, which can be done through classroom visits to observe teaching and learning process directly, especially in the selection and methods used, media utilized and the involvement of students in the learning process (E. Mulyasa, 2013).

Jones et al. as presented by Danim (2011) argues that "the face of the curriculum which contains the changes is significant in the objectives, content, teaching methods and evaluation, naturally if teachers expect advice and guidance of their headmaster". It means that principal has to really master of the school curriculum. It will be impossible for a school principal who can provide advice and guidance to teachers, while he himself does not hang 
well.

Therefore, the role of principal are coaching teachers' competence, managing curriculum development in teaching and learning activities, exercising leadership in the work as well as supervision, evaluation and reporting.

1. Managing curriculum development in teaching and learning activities

Various ways in which school principals do to foster teachers' competence in schools curriculum development and teaching and learning activities such as by;

a. Helping teachers to prepare for the annual program, the semester program, weekly and daily and evaluating the curriculum implementation.

b. Helping teachers to create lesson plans and preparing teaching aids.

2. Applying leadership in work, by;

a. Providing guidance for the assignment in this case, explaining the function direction in leading organizations as well as applying the guidance in the assignment.

b. Applying communication and cooperation in the work in this regard, explaining the meaning and function of communication in the work, explaining the meaning and function of cooperation in the work, and effective communication in the work as well as to reinforce cooperation among staffs in employment.

c. Providing motivation to the staff and employees in this respect and encouraging staff to constantly develop themselves through the provision of books, training and further education.

d. Chairing a meeting in this regard, continuing meeting according to the agreement.

3. Supervision, evaluation and reporting, by;

a. Carrying out supervision in this case guiding teacher, teaching insight / knowledge and implementing feedback from the results of supervision.

b. Evaluating the activities / programs in this case, carrying out monitoring of activities / school program, carrying out evaluation activities as well as implementing the feedback of the evaluation results.

c. Reporting; in this case, collecting material and reporting the activity.

Teachers' Competence

According to Mulyasa (2012), teacher competence is the combination of personal ability of science and social technologies which are generally establish teachers' standards competence of the teaching profession, including of materials mastery, understanding the learners, and learning educational, personal and professional development.

McLeod (1990) in the Suyanto and Jihad (2013) define competence as rational behavior to achieve the objectives required in accordance with the conditions expected. Teachers' competence themselves are the teachers' ability in implementing the obligations of responsible and worthy in stakeholders' view.

According to Louise Moqvist (2003) in Suyanto and Jihad (2013) suggested that someone had called being competence if he/she can do what should be done well. Hence, a teacher can be said that she/he has the competence to teach if he/she is able to teach their students well.

In addition, Len Holmes (1992) in the Suyanto and Jihad (2013) argued that competence is basically a description of what a person can do the work as well as any form of such work can be seen. To be able doing a job, a person must have the ability in the form of knowledge, attitudes and skills which are relevant to his/her field of work.

Majid (2005) describes that competencies possessed by each teacher will demonstrate teaching quality. Competence will be materialized in the form of knowledge and professional mastery in performing one's function as a teacher. In line with the Finch \& Crunkilton (1979), in Mulyasa (2003), competence defined as mastery of an assignment, skills, attitudes, and appreciation to support successfulness.

Based on the above definition of competence, teacher's competence can be defined as the ability to be possessed by a teacher in carrying out his/her duties and responsibilities as educator to make changes to certain subjects comprehensively in accordance with the expected conditions.

Dimensions of Teacher Competency

\section{Pedagogic Competence}

In Law No. 14 Year 2005 about teachers and lecturers, it states that pedagogical competence is the "ability to manage the students' learning". Ministry of Education (Depdiknas) (2004) calls this competence with a "competency management of learning and competence preparation lesson plan includes: of being able to describe the purpose, being capable of selecting material, being able to organize the material, determining the methods and strategies, learning resources or media in learning, compiling tools assessment, determining the valuation techniques, and being able to allocate the time as well as implementing the learning process such as, opening lessons, presenting the material, using the media and methods, using props, using communicative language, motivating students, organizing activities, interacting with students communicatively, summing up the lessons, giving feedback, and conducting the assessment, as well as the using of time effectively. 
Those competencies can be seen as the ability to plan teaching and learning program, to implement or manage the interaction, and to make an assessment. According to Suyanto and Jihad (2013), pedagogical competence that must be mastered by teachers include teacher's understanding about his/her students, the design and implementation of learning, evaluation of learning outcomes, and the development of students to actualize their potential. In detail, each competence has essential indicators as follows:

a. Understanding students in depth. In this case, teacher understands the students by using principles of cognitive development; utilizing the principles of personality; and identifying the provision of students' prior knowledge.

b. Designing learning, including of comprehending the educational foundation for the sake of learning, by essential indicators, they are to understand the foundation of education; to apply the theory of teaching and learning; to determine the learning strategies based on student characteristics, to determine the competence to be achieved, and teaching materials; and to develop a lesson plan based on the strategy chosen.

c. Implementing the learning itself. The essential indicators used are setting the foreground-background learning and implementing a conducive learning.

d. Designing and implementing an evaluation of learning by essential indicators which include of designing and implementing an evaluation process and learning outcomes on an ongoing basis by various methods; analyzing the results of the evaluation process and learning outcomes to determine mastery learning; and utilizing the results of learning assessment to improve the quality of learning programs in general.

e. Developing students to actualize their potential. The essential indicators used are facilitating students to develop various academic potential; and facilitating students to develop a range of non-academic potential.

\section{Personality Competence}

According to Hall and Lindzey (1970) in Suyanto and Jihad (2013), they suggested that individual's personality is a series of events and characteristics in the overall life and reflects on the elements of behavior repetitive, and unique. Therefore, personal competence for teachers is the personal capabilities that reflects the personality steady, stable, mature, wise, noble and dignified, and can be a role model for students. In detail, this competence consists of:

a. The personality steady and stable by essential indicators, such as acting according to the norm of law; social norms; being proud as a professional teacher; and having consistency in acting in accordance with the norms prevailing in life.

b. Mature personality. The essential indicators are showing the independence attitude as an educator and having a high work ethic.

c. Personality wise. The essential indicators consist of displaying the actions based on the, students' benefit, schools and communities and demonstrating openness in thinking and acting.

d. The noble morals and can be as an example. Here, the essential indicators are acting in accordance with the norms of religion, faith and piety, honest, sincere, helpful, and having exemplary behavior as the model for students.

e. an authoritative personality. The essential indicators consist of: having a positive effect on students behaviors and respected.

In the law about teachers and lecturers, it states that personal competence is the "ability of a stable personality, noble, wise and dignified as well as being exemplary of learners".

\section{Social Competence}

According to the Law on Teachers and Lecturers, social competence is "a teacher's ability to communicate and interact effectively and efficiently with students, fellow teachers, parents / guardians of students and the surrounding community".

While Surya (2003) suggests that social competence is required by one's ability to succeed in dealing with others. Social competence includes of skills in social interaction and fulfill its social responsibility.

Teacher social competence is one of the powers or the teacher's ability to prepare students to be good members of society as well as the ability to educate and guide the community in the face of life in the future. To carry out the role of civil society, teachers must have competencies, such as:

a. The normative aspect of education, that is to be a good teacher is not enough depend on teacher's talent, intelligence, and skill, but also must

b. act in good faith so that it is linked to the norm which is as foundation in performing their duties, considerations before selecting a professorship, and

c. Having a program that leads to the advancement of society and the advancement of education.

Suyanto and Jihad (2013) state that social competence that must be possessed by teachers are:

a. Ability to socialize and communicate effectively with students. Its essential indicators are: communicating effectively with students and understanding students' desires and expectations.

b. Ability to communicate and interact effectively with fellow educators and education personnel, for example, teacher can discuss the problems faced by students as well as the solution. 
c. Ability to communicate and interact effectively with parents or guardians of students and the surrounding community. For example, teachers can provide information about the talents, interests, and abilities of students to the parents.

Based on the above explanation, teachers' social competence is reflected through the indicators in case of teacher interaction with students, the principal, colleagues, parents, teachers and interaction with the community.

\section{Professional Competence}

According to Suyanto and Jihad (2013), they argue that professional competence is the mastery of learning materials is broad and deep to teachers mastery includes of curriculum subjects at school and substance of knowledge that overshadow the material, as well as mastery of the structure and methodology of science. Each competence has essential indicators as follows:

a. Mastering scientific substance associated with the field of study. This means that teachers must understand teaching materials in the school curriculum; understand the structure, concepts and methods of science that houses and coherent with the teaching materials; understand the relationship concept between subjects; and apply the concepts of science in teaching and learning.

b. Mastering the structure and the scientific method implies that teachers must master the steps of research and critical studies to deepen the knowledge or teaching materials.

c. Ability in organizing teaching and learning process

d. The willingness and ability to develop professionalism and personality in a sustainable manner.

Merriam (1989) as cited by Suyanto and Jihad (2013) suggests that professional competence that must be possessed by teachers are:

a. Understanding the motivation of the students.

b. Understanding students learning needs.

c. Having sufficient ability of the theory and practice.

d. Determining the needs of the user community education.

e. Having the ability to use a variety of methods and techniques of learning.

f. Having listening skills and communication (oral and written).

g. Knowing how to use the material taught in the practice of real life.

h. Having an open view to allow students to develop their interests respectively.

i. Having a desire to continue and to enrich their knowledge and continue their studies.

j. Having ability to evaluate a teaching and learning program.

Likewise, Law No. 14 Year 2005 on Teachers and Lecturers states that professional competence is the "ability of mastering the subject matter is broad and deep". In addition, Muhammad Surya (2003) says that the professional competence is a wide range of capabilities required in order to realize himself as a professional teacher. Professional competencies include expertise or skill in the art of mastering materials which should be taught along with the method, a sense of responsibility in his work and a sense of community with other teacher colleagues.

In line with that, professional competence of teachers includes the ability in terms of:

a. Understanding and being able to apply a good educational foundation philosophical, psychological, and so on,

b. Understanding and applying the theories learned in accordance with the level of development of learners behaviors,

c. Being capable of handling the subject or field of study that is assigned to him,

d. Understanding and being able to apply the appropriate teaching methods,

e. Having ability to use a variety of subjects and media as well as other learning facilities

f. Having ability to organize and implement the teaching program,

g. Having ability to carry out the evaluation of learning and

h. Having ability to motivate learners.

Depdiknas (2006) adds that professional competence includes of professional development, understanding of knowledge and mastery of academic study.

\section{Research Methods}

This study conducted on March until May 2016, at MAN I Kendari, Southeast Sulawesi, Indonesia. This research was descriptive qualitative approach which aims to provide an overview evaluation of the Principal's role in developing Master's competence in MAN I Kendari City. The subjects of this study is the Principal, and teachers who are in MAN I Kendari City. Determination of the subject of this study was conducted purposively to the teachers and the head of the madrasah. Some of interviewed teachers have similar views results in assessing and observing the head of madrasah in carrying out the role and guidance of teacher competence MAN 1 Kendari. As responsible for education in schools / 
madrasah, Head of madrasah realizes his role in fostering all staff and teachers, while the teachers of MAN I Kendari realize the importance of developing professional competence in efforts to improve their self quality and the quality of education generally. Data collection techniques used were observation, interviews, documentation and triangulation. The data analyzed by reducing, presenting and drawing conclusions. Miles and Huberman (1992) Collecting the data used in order to collect as much information in accordance with the purpose of research, and then perform data reduction is that the data obtained is written in the form of reports or detailed data. The report is based on data obtained reduced, summarized been the subject matters, which focused on the important things. After reducing the data, the next step is to present the data in the form of narrative text, and then doing a conclusion.

\section{Results and Discussion}

\section{A. Description of Research Results}

Coaching of teacher competence as a whole is divided into four aspects: Teachers Working Group (KKG), supervision, education and guidance through the program of cooperation between teachers and students' parents. All these aspects are translated into the sub aspects defined as interview guides in the form of unstructured questions. In order to reveal the principal's role in the evaluation of coaching competence of teachers, researchers compiled 8 points of the question. The results of interviews conducted by the author described as follows:

\section{a. Evaluation of principals development as leader to social competence of teachers' in MAN I Kendari}

Evaluation of the role of the principal as leader (leader) is a role that must be understood and controlled by principals in their role as leaders in order to foster the teachers' creativity as well as to encourage their improvement both a task-oriented leadership and oriented school personnel.

According the results of interviews, the principal of MAN I Kendari argued that "to build competencies social teacher, I always apply a few activities that can establish communication and good cooperation between teachers, parents and fellow teachers such as conducting KKG (group working of teachers), and then socialization between teachers and parents are usually done at certain times, as well as cooperation among teachers in doing the tasks assigned by the Principals. "(Ma'sud Ahmad, M.Pd., interview on April 20, 2016)

Based on data collection and interviews, it can be concluded that the principal has been exerting leadership in his work by implementing the communication and cooperation in the work in this regard, explaining the meaning and function of communication in the work, cooperation in the work, applying effective communication in work as well as reinforcing cooperation between teachers in the work, providing motivation to the teachers in, encouraging teachers to constantly develop themselves through the provision of books, training and further education as well as leading the meeting and following up the meeting results according to the agreement. The headmaster was a builder who must always be ready to build a good social interaction between teachers through coaching-training activities within the school and outside of school.

b. Evaluation of principal for educator development in mastering the competencies

Principal is not only as a leader but also as an educator for teachers, who aimed to show the commitment and focused on curriculum development and teaching and learning in school.

\section{c. Pedagogic Competence}

Various ways had been done by principals in fostering teachers' competence in schools curriculum development and teaching and learning activities, such as facilitating and encouraging teachers to prepare the annual program, the semester program, weekly and daily and evaluating the implementation curriculum. Then facilitate teachers to create lesson plans and preparing teaching aids.

According to the interview, the headmaster pointed out that "in terms of fostering teachers pedagogical competence, principal organized activities that can improve the ability of teachers to manage teaching materials such as including teachers in the development and training of KKG and training in schools, and through some assignment performed by the principal. (Zulrahmad, S.Pd.M.Pd. interview 22 April 2016).

From above description, the researchers concluded that in order to guide the pedagogical competence of teachers, principal conducted coaching in schools as fostering teachers' ability to manage material through duty provision for teachers to create learning programs such as the annual program, the semester program, weekly activities planning and daily activities lesson plan, not only to maximize the ability of the principals involved several coaches to develop these competencies through KKG (working group of teachers) is done once a month at the school, in carrying out its role, the principal also developed the ability to follow the activities of PSC (Principals working Group), schools and the entire contents likened to a tree then the principal as its roots, when the roots are able to absorb water and nutrients properly, then the trees will grow well and produce high quality of fruit.

\section{d. Professional competence}

In terms of professional competence, according to the interview result by asking the teachers, the informant said, "the principal always eagers to motivate teachers to develop professional capabilities in this case the ability to master the material that will be taught through the opportunity to continue their studies, provides the guide books on learning program useful for future support for the teachers' career and particularly to avoid mistakes in teaching. (Asniati, 
S.Pd.M.Pd., interview 25 April 2016).

Based on data collection, the researchers concluded that in fostering the ability of mastering the learning material, principals provided motivation and facilities in this case involving some campuses that teachers who had not graduated to magister degree to continue their studies and gain knowledge as well as the provision of books and principal to add insight and new knowledge for teachers, as well as to evaluate the implementation of curriculum and learning activities to teach well, so the teacher does not make mistakes in teaching due to maturity in mastering the material since the teacher described as a painter in the school and the students are painting to that can attract and can be enjoyed by many people then it all depends on the artist. Therefore, in order to produce qualified teacher, they must have a mastery of materials and methods to create a quality learners.

e. Evaluation of development principal as supervisor on teacher competence in MAN I Kendari

Evaluation of principal's role as a supervisor whose purpose is to conduct surveillance at regular intervals on the course of the learning process, such as supervising teacher at the ability to manage teaching materials, the ability of interaction between teachers and students as well as the ability of teachers in understanding the characteristics of students in receiving learning materials so that the learning process will be fun for students.

\section{f. Pedagogic competence}

In accordance with the results of interviews and collecting data that researchers got from the informant, it was found that the principal suggested that "performing principal role as a supervisor in fostering the pedagogical competence is through classroom supervision and superintendent at certain times which aims to know how much the teacher's ability to manage learning materials "(Ma'sud Ahmad, S.Pd.M.Pd., Interview on April 20, 2016).

\section{g. Professional competence}

Based on data collection and interviews that the authors obtained from informants, that the principal suggested that "to foster the professional competence of teachers is better done through classroom supervision that aims to determine the extent to which a teacher's ability in mastering the material and deliver material as well as the allotted time needed to teach ". (Ma'sud Ahmad, S.Pd.M.Pd., Interview on April 26, 2016)

\section{h. Personality competence}

Based on interview, the informant as the principal said that "to carry out his role as a supervisor, in fostering the personal competence of teachers is through the implementation of classroom supervision is carried out during the learning progress every day, such as the ability to comply with the rules of the school, especially teaching discipline in order to be a good role model for students. (Ma'sud Ahmad, S.Pd.M.Pd., Interview 27 April 2016)

Hence, in fostering the three competencies, the principal supervised lessons during the learning process which aims at monitoring classroom activities, such as a teacher's ability to manage the learning materials, to make lesson plan, to engage students in classroom activities as well as the ability to bring themselves within the school environment, especially in the classroom such as understanding students' characteristics so that he can tailor the learning materials to the student's interest in learning. Through classroom supervision, principal may know the strengths and weaknesses that are owned by the teachers in the school, through the advantages and disadvantages that will be as an evaluation and report to the school administration through some books like teachers supervision and books supervision from guide book. Form of evaluation by Principals as provide understanding and assignment to a teacher through the organization of the meeting, whose purpose is to discuss the advantages and disadvantages that a teacher, the results were obtained from classroom supervision activities.

In addition, another informant said that "in performing his role as principal, to provide guidance to the teachers competence, principal did not find or had constraints due to the teacher merely following the programs organized naturally by the school, since the problems that occured also at the time of implementation in the classroom, and the form of coaching is just supervising lessons. (Drs.Muis, M.Si., interview 29 April 2016).

Based on the result, it show that the principal did not find some obstacles, it is due to the coaching program is natural or run away, since the principal believes the teachers strongly understand about the coaching programs.

\section{B. Discussion}

In accordance with the results the obtained data and information on the competence of teachers in MAN I Kendari as follows:

\section{Pedagogic Competence of teachers at MAN I Kendari}

According to the results of interviews that the author got from informants, Ma'sud Ahmad, M.Pd. Head MAN I Kendari noted that to develop pedagogical competence of teachers, headmaster always provided motivation for teachers to continue their education, follow KKG, motivate them to read books, provide insights and new knowledge for teachers in managing learning materials then join meetings done once a week. "(Interview on 29 April 2016).

Principal's statement above is supported by Mudair, M.Pd. as a teacher who argued that, "teachers at MAN I Kendari, have been able to manage the learning program well. I do my thanks to the motivation accompanied by the principal as an educator". (Interview on May 1, 2016). It is supported by school personnel as the informant's, namely Drs.Muchsin Baharuddin, M.Pd. who suggested that "teachers have been able to manage such learning programs, developed 
curriculum, developed the theme, as well as some devices in making learning media and materials through KKG". (interview on May 4, 2016).

According to Raka (1984), he suggests that competence is the ability to plan teaching lesson plan includes of organizing teaching materials, planning the management of teaching and learning activities, classroom management plan, planning the use of media and teaching resources; and student achievement assessment plan for teaching benefit.

Whitney's study (2012) explains that the influence on teacher leadership is an attitude of inquiry and horizontal relationship orientation with teachers, where both of them can reduce anti-collaborative to the differences of power effect that exist in across institutional job. In this case, the principal has the task of carrying out his functions, both functions related to the educational goals achievement and conducive school climate creation to the implementation of effective and efficient teaching and learning process.

Based on description above, the researchers revealed that conducting training on the pedagogical competence of teachers is through some of the efforts made by the Principal in carrying out his duties and functions as a driving force in terms of motivating teachers through the activities and efforts to develop competencies in particular teacher's pedagogic competence. These activities can help and provide convenience for teachers to teach and have the ability to manage learning programs such as, how to develop and create a learning tool as well as a good classroom management.

\section{Personality competence of teachers in MAN I Kendari}

According to the results of interviews the authors obtained from informants, namely Asniati S.Pd.M.Pd. as deputy principal curriculum in MAN I Kendari, she noted that to conduct training for the competence of teacher's personality, the headmaster had to supervise, control and guidance to some of the teacher's behavior as behavior that steady and stable, mature attitude, personal wise, noble and can be the role models for students and personal dignity through his role as a supervisor. "(interview on April 30, 2016)

The statement was supported by Drs.Muis, M. Pd as teacher in MAN I Kendari who argued that, teachers are being monitored every behavior conducted in the school, especially behavior that leads to discipline in carrying out the task. "(Interview on May 5, 2016)

The statement was supported by Dr.Zulrahmat, S.Pd.M.Pd. as one of the teachers in MAN I Kendari. He argued that "in carrying out the task, the principal always be discipline, especially in teaching, in the event of violation, and the principal way in giving punishment". (Interview on May 10, 2016)

In line with that, Surya (2003) calls this personal competence as personal competence, that is, the ability of a teacher personally in order to become a good teacher. Personal competence includes of personal capabilities with respect to understand self-acceptance, self-direction and self-realization. While the teacher competence is more particularly be empathetic, open, authoritative, responsible and able to assess the teacher personally. Meanwhile, according to Arikunto (1993), personal competence requires that teachers have a solid personality to become the source of inspiration for the subject, and exemplary student.

Hartley's research (2007) suggests that the emergence of leadership has beed characterized by supporting evidence, there is little evidence of a direct causal relationship between leadership and students.

Hence, in an effort to provide guidance to the competence of the teacher's personality, the principal guide the teachers' competence by applying several rules as a teacher. Based on this rule, teachers in MAN I Kendari always be active and on punctual for their presence in the school.

\section{Professional competence of teacher in MAN I Kendari}

In accordance with interview of Drs.Mudair M.Pd as one of the teachers of MAN 1 Kendari, he stated that "to direct the professional competence of teachers, principal conducted classroom supervision on scat learning process takes place, which aims to monitor the teaching and learning process in terms of identifying teachers' ability to master the material that will be taught ". (Interview on April 2, 2016)

The above statement is supported by Baharuddin Drs.Muchsin as the teacher in MAN I Kendari. He said that "teachers already have the ability to master the material that will be taught to the students, in accordance with professionalism by always reading books and actively follow KKG" (Interview on May 6, 2016)

The two statements above are supported by the next informant namely, Drs.Muis M.Pd as the teacher in MAN I Kendari. He revealed that "to be able to support their work in the future as well as to have the ability in mastering the material to be taught, the teachers in MAN I Kendari are always ready to carry out the direction given by Principal. It is done by motivation teachers to pursue their education and has always actively read and seek knowledge through the facilities provided by the headmaster as reference books in the school library ". (Interview on May 7, 2016)

Idochi and Amir(2004) states that the professional capabilities include of subject mastery and the basic concepts of science nautical taught and appreciation of grounding and insight into education and teacher training, as well as mastery of the processes of education, teacher training and student learning.

Moreover, Arikunto (1993) says that the professional competence requires teachers to have a broad knowledge of the subject matter and the field of study that will be taught as well as mastery of the methodology that is mastering 
theoretical concepts, choosing the appropriate method and being able to use them in the learning process.

The Valentin and Prater (2011) principal leadership have some behaviors, promote instructional and curriculum improvements related to academic achievement in transformational leadership and identify vision and provide the right model for the greatest achievement

Teachers in MAN I Kendari according to the recent study show that they were able to carry out their duties and obligations professionally. It is based on the principal efforts to maximize the teachers' potential, through several attempts in motivating teachers to continue his studies for teachers who have not completed their studies to the master degree, the provision of guidance based on the results of classroom supervision conducted by the principal and assisted by some review activities of supervisors as well as the availability of reference books to teaching and learning for teachers. Here, the researchers state that the teachers in MAN I Kendari always tried to continue learning and developing their skills in understanding the learning programs through the development of the principal in order to provide qualified teachers. Moreover, it will affect the next generation by good character in competitive era of today.

\section{Social Competence of teacher in MAN I Kendari}

In accordance with the results of teacher social competence, the researchers interviewed the informant, namely Asniati S.Pd.M.Pd., She argued that "for supervision to the teachers' social competence, the principal applied his leadership in the work to establish some social activities in which include of some activities by cooperation between teachers and students' parents, joining KKG, cooperation among teachers with colleagues so they can discuss about the problems faced by students and provide a solution, as well as activities in the promotion of social interaction between teachers and students which held once a month at MAN I Kendari ". (Interview on April 25, 2016)

The above statement is supported by the statements of informants, namely Drs.Mudair M.Pd who said that "through such activities the teachers have been able to interact with parents to inform each other about their children situation when they are cat school or at home, with teachers and parents. That such information would greatly help in understanding the students' characteristics so that there is a good cooperation in providing education for children". (Interview on May 11, 2016)

The two statements above are supported by the next informant, namely Dra.St.Aminah M.Ag as one of teachers in MAN I Kendari. She revealed that "teachers in Kendari MAN have been able to get along and communicate effectively with students, for instance to communicate effectively with students. Therefore, teachers can understand students' desires and expectation and be able to communicate and interact effectively with fellow educators and education personnel, such as, teachers can discuss the problems faced by students and provide the solutions ". (Interview on May 13, 2016).

In addition, Johnson as cited by Idochi and Amir (2004) states that social skills include the ability to adapt the demands of work and the environment at the time when he brought his duties as a teacher. Likewise, Arikunto (1993) suggests that social competence requires teachers to have good social communication skills with students, fellow teachers, principals, employee administration, even by members of the public.

Hall, Gunter, and Brogg research (2012) the official development and discursive practices normative related to the leadership and potential for ideological social control of teachers examining in social, cultural and political environments.

Hence, social competence of teachers can be fostered by principal in training teachers in leadership in the work to organize several activities that make up the interaction between teachers and students so that teachers can understand the desires and expectations of the students in the learning process in school. They also can interact with the principal and colleagues, teacher interaction with parents, teachers and interaction with the community so that teachers can provide information about the talents, interests, and abilities of students to their parents.

From the above description has been the author presented, the researchers state that the teachers in MAN I Kendari have been able to interact well in school and in society, it is useful to improve their ability to be more socialize, because creating good teamwork starts from the good social relationship.

\section{Conclusion}

Evaluation of the principal role in fostering teachers' competence in MAN I Kendari run well, as reflected in the role as leader. (1)The principal provided guidance related to the cooperation between school personnel, especially teachers, and students' parents related to education for students both at school and at home as well as socialization between teachers of MAN I with other teachers from different school through KKG (working group of teachers) which aims to improve the social competence of teachers in MAN I Kendari. (2) Meanwhile, in role as educator, headmaster attempted to do some coaching of pedagogical competence and professional competence in the provision of facilities for continuing education, provision of guide books for teachers about the learning program and facilitated teachers to participate actively in KKG that aims to enhance the teacher's ability to control and manage learning materials properly, (3) then the role of supervisor (supervisor) was in carrying out his role as supervisor of the principal by fostering pedagogical competence and personality in the form of activities to supervise the class, held a meeting related to the results of supervision activities of the learning process, preparation of learning programs as well as the interaction between teachers and students in the classroom, and coaching teachers through the school rules in this case giving 
reinforcement through reward or punishment for the teacher when they were in violation of these rules.

\section{References}

Act No. 14 of 2005 on Teachers and lecturers. Bandung: Penerbit Fokus Media.

Arikunto, S. (1993). Human educational management. Jakarta: Rineka Cipta.

Danim, S. (2012). Educational innovation in the effort of developing professional staff and teachers. Bandung: Pustaka Setia.

Daryanto. (2001). Educational Administration. Jakarta: Rineka Cipta

Depdiknas. (2004). Law of national education system. Jakarta: Grafindo.

Depdiknas. (2006). Principal of Kindergarten, Primary School, Junior high school, senior high school, secondary school, and inclusion school (TK, SD, SMP, SMA, SMK \& SLB). Jakarta : BP. Cipta Karya.

Djafri, N. (2016). Leadership Management. Yogyakarta: Deepublisher.

Government Regulation No. 19 Year 2005 on National Education Standards

Hall, D. G., \& Helen Bragg, J. (2012). Leadership, New Public Management and the re-modelling and regulation of teacher identities. International Journal of Leadership in Education, 1-18.

Hartley, D. (2007). The Emergence of Distributed Leadership in Education: Why nom?. British Journal of Educational Studies- BRIT J EDUCSTUD, 55(2), 202-214. https://doi.org/10.1111/j.1467-8527.2007.00371.x

Idochi, A., \& Amir, Y. H. (2000). Educational administration, theory, concept and issues. Bandung: Bumi Siliwangi.

Majid, A. (2005). Learning planning: improving teachers competence standard. Bandung: PT Remaja Rosdakarya.

Miles, M. B., \& dan Huberman, A. M. (1992). Analysis of qualitative data: source of new methods. Jakarta : UI Press.

Mulyasa, E. (2003). School based management: concept, strategy, and implementation. Bandung: PT. Remaja Rosdakarya.

Mulyasa, E. (2004). Being professional principal in succeeding school based management and competence based curriculum. Bandung: PT. Remaja Rosdakarya.

Mulyasa, E. (2012). Competence standard and teacher sertification. Bandung: PT Remaja Rosdakarya.

Mulyasa, E. (2013). Principal Management and Leadership. Jakarta: Bumi Aksara.

Raka, T. J. (1984). Guidelines of assessing teachers' competence. Jakarta: Dirj en Pendidikan Tinggi Depdikbud.

Surya, M. (2003). Psychology of learning an instruction. Bandung: Yayasan Bakti winaya.

Suyanto \& Hisyam Jihad. (2000). Educational feflection and reformation in Indonesia in the 3rd Millenium. Yogyakarta : Adi Cita.

Suyanto dan Jihad Asep. (2013). Being professional teacher. Ciracas: Erlangga.

Valentine, J. W., \& Prater, M. (2011). Instructional, Transformational, and Managerial Leadership and Student Achievement: High School Principals Make a Difference. NASSP Buletin, 95(1), 5-30. https://doi.org/10.1177/0192636511404062

Vennebo, K. F., \& Ottesen, E. (2012). School Leadership: Constitution and Distribution. International Journal of Leadership in Education, 15(3), 255-270. https://doi.org/10.1080/13603124.2011.624642

Whitney, A. E. (2012). When university faculty nurture teacher leadership: Horizontal practices and values in a professor's work with teacher. Journal: International Journal of Leadership in Education, 1-23.

\section{Copyrights}

Copyright for this article is retained by the author(s), with first publication rights granted to the journal.

This is an open-access article distributed under the terms and conditions of the Creative Commons Attribution license (http://creativecommons.org/licenses/by/4.0/). 